\title{
PENUMBUHAN MINAT BACA ANAK USIA 5 - 6 TAHUN DI KOMPLEK LANATA RESIDENCE 2
}

\author{
Farisa Khalidia ${ }^{1}$, Rohita ${ }^{1}$ \\ ${ }^{1}$ Pendidikan Anak Usia Dini, Fakultas Psikologi dan Pendidikan, Universitas Al-Azhar \\ Indonesia, Komplek Masjid Agung Al-Azhar Jl. Sisingamangaraja, Jakarta Selatan, 12110
}

E-mail: rohita@uai.ac.id

\begin{abstract}
ABSTRAK - Minat baca anak-anak pada saat ini perlu ditumbuhkan. Berdasarkan hasil observasi diketahui bahwa anak-anak yang tinggal di Komplek Lanata Residence 2 memiliki minat baca yang rendah. Peran orangtua sangat dibutuhkan untuk menumbuhkan minat baca anak. Penelitian ini bertujuan untuk mengetahui proses penumbuhan minat baca anak di Komplek Lanata Residence 2, Jakarta Selatan. Subjek penelitian ini berjumlah 11 orang yang terdiri 5 (lima) orang ibu, 3 (tiga) orang anak perempuan dan 2 (dua) orang anak laki-laki. Penelitian ini menggunakan pendekatan kualitatif deskriptif dengan teknik pengumpulan data menggunakan observasi, wawancara, dan dokumentasi. Teknik analisis data yang digunakan adalah teknik analisis dari Miles and Huberman yang prosesnya dilakukan dalam tiga tahap yaitu reduksi data, display data, dan kesimpulan (triangulasi data). Hasil penelitian menunjukkan bahwa proses penumbuhan minat baca pada anak-anak di Komplek Lanata Residence 2 dilakukan dengan menggunakan metode tiru bunyi, coba tulis, latih baca, tebak contoh, dan latih kata dan kalimat. Media yang digunakan adalah buku bacaan kisah nabi, buku pelajaran, buku cerita atau novel.
\end{abstract}

Kata Kunci: penumbuhan, minat baca, anak usia 5 - 6 tahun

ABSTRACT - Reading interest of children at this time needs to be grown. Based on observations it is known that children who live in the Lanata Residence 2 Complex have low reading interest. The role of parents is needed to foster children's interest in reading. This study aims to determine the process of growing interest in reading children in Komplek Lanata Residence 2, South Jakarta. The subject of this study amounted to 11 people consisting of 5 (five) mothers, 3 (three) girls and 2 (two) boys. This study uses a descriptive qualitative approach with data collection techniques using observation, interviews, and documentation. The data analysis technique used is an analytical technique from Miles and Huberman whose process is carried out in three stages, namely data reduction, data display, and conclusions (data triangulation). The results showed that the process of developing reading interest in children in the Lanata Residence 2 Complex was carried out using the sound method, try writing, practicing reading, guessing examples, and practicing words and sentences. The media used are reading books of the prophet, textbooks, story books or novels.

Keyword:growing, reading interest, children aged 5-6 years 


\section{PENDAHULUAN}

\section{A. Latar Belakang}

$\mathrm{A}$ nak usia dini adalah anak yang sedang berada pada masa tumbuh kembang. Ditandai dengan perilaku aktif, dinamis, antusias dan hampir selalu ingin tahu terhadap apa yang dilihat dan didengarnya, seolah-olah tak pernah berhenti untuk belajar. Anak juga memiliki dunia dan karakteristik tersendiri yang jauh berbeda dari dunia dan karakteristik orang dewasa. Hal ini di masa pertumbuhan dan perkembangan anak sedang meningkat sehingga diperlukan stimulasi yang optimal untuk mendukung tumbuh kembangnya. Untuk bisa memberikan stimulasi maka diperlukan sebuah pendidikan yang tepat untuk anak usia dini sesuai dengan pasal Permendikbud tentang Pendidikan Anak Usia Dini.

Permendikbud Nomer 146 Tahun 2014 Pasal 1 menyebutkan "Pendidikan Anak Usia Dini, yang selanjutnya disingkat PAUD, merupakan suatu upaya pembinaan yang ditujukan kepada anak sejak lahir sampai dengan usia 6 (enam) tahun yang dilakukan melalui pemberian rangsangan pendidikan untuk membantu pertumbuhan dan perkembangan jasmani dan rohani agar anak memiliki kesiapan dalam memasuki pendidikan lebih lanjut". Berdasarkan Permendikbud tersebut, diketahui anak usia 5-6 tahun harus memiliki kesiapan untuk memasuki pendidikan lebih lanjut, salah satu tahapan anak diperlukan adalah kemampuan membaca, agar kemampuan anak membaca tercapai perlu terlebih dahulu ditumbuhkan minat membaca pada diri anak. Adanya minat akan membuat anak senang dan cepat dalam mengenal huruf dan membaca.

Minat baca adalah keinginan orang perseorangan pada bacaan yang dapat memberikan manfaat dan berhasil guna pada diri pribadi sehingga menimbulkan aktivitas dan kreativitas untuk membaca (Nurhadi, 2004: 26). Salah satu contohnya yaitu dengan orangtua memberikan buku cerita bergambar seperti princess atau robot dan serta gambar dengan colour full, sehingga anak tertarik untuk membacanya.

Salah satu upaya stimulasi yang dilakukan oleh orangtua di lingkungan keluarga untuk menumbuhkan minat yang menjadi sebuah kebiasaan misalnya membaca buku sebelum tidur bersama ayah atau ibu. Baik yang berupa dukungan material maupun moral akan berdampak positif bagi perkembangan membaca anak. Jika sejak usia dini anak-anak dikenalkan dengan bahan bacaan dan kebiasaan membaca, maka diharapkan kebiasaan itu akan melekat hingga tumbuh dewasa.

Terkait dengan hal itu maka peneliti melakukan penelitian untuk mengetahui proses penumbuhan minat baca anak usia 5-6 tahun terutama yang ada di Komplek Lanata Residence 2.

\section{B. Fokus Penelitian}

Sesuai dengan latar belakang masalah, maka yang menjadi fokus penelitian secara umum adalah " Proses penumbuhan minat baca anak usia 5-6 tahun di Komplek Lanata Residence 2". Adapun sub fokus dalam penelitian tentang gambaran tentang minat baca anak usia 5-6 tahun adalah :

1. Bagaimanakah proses penumbuhan minat baca untuk anak usia 5-6 tahun di Komplek Lanata Residence 2?

2. Bagaimanakah metode yang digunakan dalam penumbuhan minat baca untuk anak usia 5-6 tahun di Komplek Lanata Residence 2 ?

3. Bagaimanakah media yang digunakan dalam penumbuhan minat baca untuk anak usia 5-6 tahun di Komplek Lanata Residence 2?

\section{A. Tujuan Penelitian}

Tujuan umum penelitian ini untuk mendeskripsikan prosespenumbuhan minat baca anak usia 5-6 tahun di Komplek Lanata Residence 2, yaitu:

1. Memberi gambaran proses penumbuhan minat baca untuk anak usia 5-6 tahun di Komplek Lanata Residence 2 .

2. Memberi gambaran metode yang digunakan dalam penumbuhan minat baca untuk anak usia 5-6 tahun di Komplek Lanata Residence 2.

3. Memberi gambaran media yang digunakan dalam proses penumbuhan minat baca untuk anak usia 5-6 tahun di Komplek Lanata Residence 2.

\section{B. Manfaat Penelitian}

Berdasarkan tujuan penelitian yang telah diuraikan di atas, maka peneliti mengharapkan 
adanya manfaat dari penelitian yang dilakukannya. Oleh karena itu dalam penelitian ini diharapkan mempunyai manfaat penelitian sebagai berikut :

Secara praktis, penelitian ini diharapkan dapat memberikan manfaat kepada:

1. Orangtua

Hasil peneltian dapat memberi suatu pengetahuan atau pengajaran cara agar orangtua dapat menumbuhkan minat baca anak atau cara mengajak anak dirumah dengan kegiatan membaca usia 5-6 tahun

2. Guru

Salah satu cara guru untuk dapat menumbuhkan tumbuhnya minat baca anak-anak disekolah salah satunya yaitu perkembangan bahasa dengan membaca dan menulis usia 5-6 tahun

3. Mahasiswa/i PAUD

Salah satu referensi untuk menambah wawasan dan pengetahuan untuk calon guru dalam kegiatan menumbuhkan minat baca anak usia 5-6 tahun

\section{KAJIAN TEORI}

\section{A. Minat}

Pada saat anak usia dini anak mempunyai masa keemasan atau yang disebut golden age yang berati anak itu cepat dalam menangkap apa yang anak lihat dan anak pelajari. Diusia ini anak memiliki rasa ingin tahu yang besar, mencoba sesuatu hal yang baru, serta sangat aktif dalam melakukan hal apapun. Dalam hal ini jika anak sudah menyukai hal tersebut akan dilakukan dengan senang hati dan riang gembira.

Dalam setiap melalukan sesuatu yang diperlukan adalah minat, karena jika minat tidak ada pada diri sendiri maka tidak maksimal dalam mengerjakan sesuatu. Hal yang dikerjakan akan terasa sia-sia. Lebih baik melakukan sesuatu dengan minat, jika seseorang memiliki minat akan terfokus dan bersungguh-sungguh dalam melakukan hal tersebut dan mendapatkan hasil yang baik. Kamus lengkap psikologi (dalam Chaplin, 2008: 255), dituliskan bahwa minat (interest) adalah (1) satu sikap yang berlangsung terus menerus yang memolakan perhatian seseorang, sehingga membuat dirinya jadi selektif terhadap objek minatnya; (2) perasaan yang menyatakan bahwa satu aktivitas, pekerjaan, atau objek itu berharga atau berarti bagi individu; (3) satu keadaan motivasi, atau satu set motivasi, yang menuntun tingkah laku menuju satu arah (sasaran) tertentu.

\section{B. Membaca}

1. Pengertian Membaca

Membaca seperti yang seperti dikatakan oleh Rahmi (2008: 2) yaitu membaca suatu hal yang rumit karena melibatkan banyak hal. Membaca suatu kalimat harus dapat dimengerti karena jika seseorang tidak mengerti maka informasi apa yang telah dibaca tidak akan didapat. Setelah dapat mengerti suatu kalimat tersebut seseorang akan menafsirkan suatu pesan yang ada di dalam suatu kalimat tersebut atau yang disebut dengan proses recording dan decoding seperti yang dikatakan oleh Anderson dalam Wahyuni (2010: 8) membaca permulaan dalam pengertian ini adalah membaca permulaan dalam teori keterampilan, maksudnya menekankan pada proses penyandian membaca secara mekanikal. Membaca permulaan yang menjadi acuan adalah membaca merupakan proses recording dan decoding.

2. Metode Membaca

Ketika anak mulai belajar membaca anak tidak langsung lancar dalam membaca. Anak diharuskan mengenal huruf abjad terlebih dahulu agar ketika membaca anak diharapkan dapat lancar dalam membaca. Anak-anak akan lebih menyukai belajar membaca sambil bermain daripada belajar melalui teks buku bacaan. Ketika anak sudah mulai tertarik dengan bacaan atau tulisan anak ingin mengetahui lebih banyak lagi seperti meniru tulisan, bermain tebak-tebakan, dan melatih dalam membaca kata maupun kalimat seperti yang dikatakan oleh Atikah (2011: 3) menyatakan, sebelum diajarkan membaca, anak diperkenalkan pada huruf a-z agar dapat merangsang minat anak belajar membaca, huruf-huruf tersebut didampingi oleh gambar dengan menggunakan metode lima langkah lancar membaca yaitu : tiru bunyi, coba tulis, latih baca, tebak contoh, dan latih kata dan kalimat.

3. Media Membaca 
Ketika anak belajar membaca anak memerlukan suatu yang sesuai, mudah, menarik, dan mempunyai manfaat dalam belajar membaca atau memunculkan minat di dalam diri agar apa yang ia pelajari dapat mudah diserap oleh anak dan dapat dipahami secara keseluruhan seperti yang dikatakan oleh Mulyanto dan Leong (2009: 3) menjelaskan kriteria media pembelajaran yang baik idealnya meliputi 4 hal utama, yaitu :

a. Kesesuaian atau relevansi, artinya media pembelajaran harus sesuai dengan kebutuhan belajar, rencana kegiatan belajar, program kegiatanbelajar, dan karakteristik peserta didik.

b. Kemudahan, artinya semua isi pembelajaran melalui media harus mudah dimengerti, dipelajari atau dipahami oleh peserta didik dan sangatoperasional dalam penggunaannya.

c. Kemenarikan, artinya media pembelajaran harus mampu menarik maupun merangsang perhatian peserta didik, baik tampilan, pilihan warna, maupun isinya.

d. Kemanfaatan, artinya isi media pembelajaran harus bernilai atau berguna, mengandung manfaat bagi pemahaman materi pembelajaran serta ketidakmubaziran atau sia-sia apalagi merusak anak

\section{Perkembangan Bahasa Anak Usia 5-6 Tahun}

1. Pengertian Perkembangan Bahasa Usia 5-6 Tahun

Anak usia dini harus diberikan perhatian yang istimewa oleh orangtua dalam proses tumbuh kembang anak, karena diusia inilah anak banyak belajar dan cepat tanggap. Orangtua juga diharapkan dalam proses tumbuh kembang harus memperhatikan apakah anak tumbuh sesuai usianya atau tidak. Karena jika ada perkembangan yang lambat atau ada sesuatu yang berbeda dari anak lain harus diwaspadai karena dapat mempengaruhi perkembangannya di masa yang akan datang seperti yang dikatakan oleh Sujiono (2009: 54) perkembangan merupakan suatu proses yang bersifat kumulatif, artinya perkembangan terdahulu akan menjadi dasar bagi perkembangan selanjutnya. Oleh sebab itu, apabila terjadi hambatan pada perkembangan terdahulu maka perkembangan selanjutnya cenderung akan mendapat hambatan.

2. Karakteristik Perkembangan Bahasa Anak Usia 5-6 Tahun

Anak adalah makhluk yang unik, setiap anak yang lahir di dunia memiliki perbedaan, di dunia ini tidak ada pun yang sama persis sekalipun mereka kembar seperti yang dikatakan Sujiono (2008: 7) usia 5 tahun merupakan masa periode prasekolah karena pada saat ini sebagian besar anak-anak sudah mulai mengikuti pendidikan formal. Inilah masa penting untuk mengembangkan semua kemampuan fisiknya agar ia sukses menghadapi tantangan di jenjang sekolah dasar.

Menurut Yusuf (2007: 23) pada anak usia 5-6 tahun kedalam usia prasekolah. Dimana masa ini anak mulai memasuki dunia Taman Kanak-Kanak yang merupakan masa dimana anak harus mulai beradaptasi dengan lingkungan baru. Seperti yang dikatakan Yusuf (2007: 6) Pada usia 5-6 tahun Piaget mengelompokkan anak ke dalam masa praoperasional dimana anak mulai menggunakan simbol-simbol untuk mempresentasikan dunia (lingkungan) secara kognitif. Simbol-simbol seperti katakata dan bilangan dapat menggantikan objek, peristiwa dan kegiatan (tingkah laku yang tampak).

\section{METODE PENELITIAN}

\section{A. Waktu dan Tempat Penelitian}

1. Tempat Penelitian

Lokasi penelitian adalah objek penelitian dimana kegiatan penelitian dilakukan. Peneliti melakukan penelitian ini di Komplek Lanata Residence 2, yang berlokasi di Jl. Aselih Jagakarsa Ciganjur, Jakarta Selatan. Peneliti memilih di lingkungan ini karena terdapat anak-anak yang berusia 5-6 tahun yang merupakan AUD, sehingga memudahkan peneliti untuk mencari informasi tetang minat baca anak usia dini yang berada di komplek ini. 
2. Waktu Penelitian

Waktu penelitian yang digunakan peneliti untuk melaksanakan sebuah proses penelitian. Mulai dari penetapan judul sampai pada proses pelaporan hasil penelitian dilaksanakan dari bulan April 2016 hingga Maret 2017.

\section{B. Metode dan Pendekatan Penelitian}

Berdasarkan permasalahan yang peneliti kaji, yaitu Subjek penelitian adalah anak-anak yang berada di Komplek Lanata Residence 2 Subjek terdiri dari $1 \mathrm{RT}$, orangtua dari subjek yang dipilih sebanyak 5 orang anak yang teridiri dari 5 orang ibu. 3 anak perempuan dan 2 anak laki-laki, Jumlah dari seluruh subjek penelitian ada 11 orang.

\section{Metode dan Pendekatan Penelitian}

Berdasarkan permasalahan penelitian, yaitu tentang Proses Penumbuhan Minat Baca Anak Usia 5-6 Tahun di Komplek Lanata Residence 2, maka peneliti ini menggunakan metode penelitian kualitatif. Digunakan pendekatan ini karena ingin mendapatkan data dengan perilaku anak tentang minat membaca juga ingin mengetahui riwayat dari sang anak tersebut. Strauss \& Corbin (2007: 4) menulis, istilah penelitian kualitatif dimaksudkan sebagai jenis penelitian yang temuan-temuannya tidak diperoleh melalui prosedur statistik atau bentuk hitungan lainnya.

\section{Sumber Data}

Sumber data penelitian disesuaikan dengan tujuan diadakannya penelitian. Sumber data yang dimaksud pada penelitian ini adalah sumber data dimana peneliti mendapatkan data (Arikunto, 2002: 10) yang terdiri dari :

\section{Data Primer}

Data primer adalah sumber data yang langsung memberikan data kepada pengumpul data (Sugiyono, 2005: 62). Peneliti hendak mengumpulkan data primer yang didapatkan melalui wawancara langsung dari anak yang menjadi subjek dan juga orangtua/ ibu dari subjek anak tersebut tentang Penumbuhan Minat Baca Anak Usia 5-6 Tahun di Komplek Lanata Residence 2.

Subjek penelitian terdiri dari: 3 anak perempuan, 2 anak laki-laki dan 5 orang ibu. Dengan objek penelitiannya adalah
Penumbuhan Minat Baca Anak Usia 5-6 Tahun di Komplek Lanata Residence 2

2. Data Sekunder

Data sekunder menurut Sugiyono (2005: 62) adalah sumber data yang tidak langsung diperoleh pengumpul data, misalnya alat perekam dan dokumen. Alat perekam yang digunakan adalah berupa handphone untuk mendapatkan data-data yang akan diperoleh peneliti. Data-data yang dikumpulkan berupa foto-foto dan video aktifitas anak terkait membaca di Komplek Lanata Residence 2.

\section{E. Teknik Pengumpulan Data}

Metode pengumpulan data dalam penelitian kualitatif yang terpenting untuk digunakan adalah observasi, wawancara, dan dokumentasi

1. Observasi

Menurut Dimyati (2013), menyatakan bahwa metode observasi adalah metode pengumpulan data penelitian dengan melalui pengamatan terhadap objek yang diteliti. Dalam metode observasi yang digunakan oleh peneliti untuk mengumpulkan data yaitu penelitian yang berupa perilaku, kegiatan, atau yang sedang dilakukan oleh subjek penelitian tersebut. Menurut Sugiyono (2011: 227), bahwa observasi ini dapat digolongkan menjadi empat bagian yaitu, partisipasi pasif, partisipasi moderat, observasi terus terang atau tersamarkan, dan partisipatif lengkap.

Dalam hal ini peneliti memilih observasi partisipasi pasif dikarenakan peneliti hanya mengamati atau melihat saja bukan turut serta dalam kegiatan atau aktivitas anak tersebut. Selain itu peneliti akan melakukan observasi terus terang karena peneliti sudah meminta izin terhadap orangtua subjek yang ingin diteliti akan melakukan penelitian, juga observasi tersamarkan kepada subjek anak tersebut.

\section{Wawancara}

Menurut Moleong (2007: 186), wawancara merupakan percakapan dengan maksud tertentu. Percakapan itu dilakukan oleh dua orang pihak secara tatap muka, yaitu pewawancara (interviewer) yang mengajukan pertanyaan dan terwawancara (interviewee) yang memberikan jawaban atas pertanyaan yang diberikan. Pedoman 
wawancara ini berisi pertanyaan-pertanyaan mendasar yang nantinya akan dikembangkan oleh peneliti saat wawancara berlangsung. Jenis wawancara yang peneliti pilih adalah wawancara mendalam (indepth interview) dengan mengajukan pertanyaan secara langsung kepada informan yang telah peneliti siapkan pertanyaanpertanyaannya menggunakan pedoman wawancara untuk mendapatkan informasi secara lengkap, mendalam, dan komperhensif sesuai tujuan penelitian. Saat dilakukannya wawancara, pengumpul data menggunakan alat perekam suara untuk merekam informasi yang diberikan.

Adapun data yang dihasilkan dari wawancara oleh 5 orang ibu, dan juga 5 orang anak, jadi keseluruhan peneliti mewawancarai ada 1 orang. Wawancara di ikuti ke dalam pedoman wawancara orangtua dan wawancara anak dengan kategori kode catatan. CWO1 untuk hasil wawancara dengan orangtua ke-1, CWO2 untuk hasil wawancara dengan orangtua ke-2, CWO3 untuk hasil wawancara dengan orangtua ke-3, CWO4 untuk hasil wawancara dengan orangtua ke- 4 , CWO5 untuk hasil wawancara dengan orangtua ke-5. Sedangkan CWA1 untuk hasil wawancara dengan anak ke-1, CWA2 untuk hasil wawancara dengan anak ke-2, CWA3 untuk hasil wawancara dengan anak ke-3, CWA4 untuk hasil wawancara dengan anak ke-4, CWA5 untuk hasil wawancara dengan anak ke-5 di Komplek Lanata Residence 2.

\section{F. Instrumen Penelitian}

Instrumen yang digunakan dalam penelitian adalah pedoman observasi, pedoman wawancara.

1. Pedoman Observasi

Pedoman observasi akan digunakan untuk mengamati Gambaran Minat Baca Anak Usia 5-6 Tahun di Komplek Lanata Residence 2. Pedoman observasi ini terdiri dari 2 kolom. Kolom pertama adalah pernyataan kegiatan yang didalamnya terdiri beberapa indikator yang isinya peneliti pilih lagi kemudian peneliti amati pada pelaksanaan penumbuhan minat baca pada anak usia 5-6 tahun, pada kolom kedua diisi dengan memberikan tanda centang $(\sqrt{ })$ pada kolom (ya) jika melakukan sesuai indikator tersebut, sedangkan tanda centang $(\sqrt{ })$ pada kolom (tidak) jika tidak melakukan kegiatan sesuai indikator tersebut.

\section{Pedoman Wawancara}

Pedoman wawancara berisi garis besar pokok-pokok masalah yang dijadikan sebagai dasar dalam mengajukan pertanyaan kepada narasumber penelitian. Untuk hasil wawancara ketus RT diberi kode (CWRT), orangtua diberi kode (CWOT), wawanacara anak diberi kode (CWA).

\section{G. Analisis Data}

Menurut Bodgan dan Biken (dalam Moleong, 2005: 248) analisis data kualitatif adalah upaya yang dilakukan dengan jalan bekerja dengan data, mengorganisikan data kualitatif adalah upaya yang diakukan dengan jalan bekerja dengan data, mengorganisasikan data, memilah-milihnya menjadi satuan yang dapat dikelola, mencari dan menemukan pola, menemukan apa yang penting, dan apa yang dipelajari, dan memutuskan apa yang akan diceritakan kepada oranglain

Analisis data yang digunakan pada penelitian ini adalah analisis data dilapangan model Miles and Hubermen. Menurut Miles and Huberman dalam (Sugiyono, 2011: 247), aktivitas dalam analisis data kualitatif dilakukan secara interaktif dan berangsung secara terusmenerus sampai tuntas, sehingga datanya sudah penuh. Aktivitas dalam data ini, yaitu data reduction, data display, dan conclusiondrawing/ verification. Mereduksi data berati merangkum data yang sudah terkumpul dan dipilih sah diberi kode oleh peneliti. Wawancara diberi kode $\mathrm{CW}$ dan dokumentasi diberi kode CD.

Setelah data direduksi, maka langkah selanjutnya adalah mendisplaykan data. Di dalam penelitian kualitatif, penyajian data bisa dilakukan dalam bentuk uraian singkat, bagan, hubungan antar kategori, yang paling sering digunakan untuk menyajikan data dalam penelitian kualitatif adalah dengan teks yang bersifat naratif. Selanjutnya disarankan, dalam melakukan display data, selain dengan teks yang naratif, juga dapat berupa grafik, matrik, network (jejaring kerja) dan chart.

Langkah ketiga dalam analisis data kualitatif menurut Miles and Huberman adalah penarikan kesimpulan dan verifikasi. 
Kesimpulan awal yang dikemukakan masih bersifat sementara, dan akan berubah bila tidak dikemukakan bukti-bukti yang kuat yang mendukung pada tahap pengumpulan data berikutnya. Tetapi apabila kesimpulan yang dikemukakan pada tahap awal, didukung oleh bukti-bukti yang valid dan konsisten saat peneliti kembali ke lapangan mengumpulkan data, maka kesimpulan yang dikembalikan merupakan kesimpulan kredibel.

\section{H. Keabsahan Data}

Keabsahan data penelitian dapat diketahui dengan menggunakan kredibilitas. Kredibiltas adalah kesesuaian antara konsep peneliti dengan konsep responden. Kriteria keabsahan data diterapkan dalam rangka membuktikan temuan hasil lapangan dengan kenyataan yang diteliti di lapangan. Keabsahan data dilakukan dengan meneliti kredibilitasnya menggunakan teknik triangulasi. Teknik triangulasi adalah pengecekan data dari berbagai sumber dengan berbagi cara, dan berbagi waktu. Maka dengan demikian terdapat triangulasi sumber, triangulasi teknik pengumpulan data, dan waktu (Sugiyono, 2011: 273).

Adapun jenis triangulasi yang dipilih peneliti ialah triangulasi teknik. Teknik triangulasi ialah menghubungkan data dari hasil wawancara, observasi dan dokumentasi. Pada penelitian ini peneliti memilih triangulasi sumber karena data yang sudah didapat bisa dilakukan pengecekan ulang terhadap ketiganya, yaitu kesesuaian data antara hasil wawancara, hasil observasi, dan dokumentasi dengan keadaan yang terjadi di lapangan serta data yang di dapat. Peneliti juga menggunakan triangulasi waktu karena peneliti melakukan di lingkungan komplek rumah jadi peneliti mengikuti waktu dari pihak orangtua subjek tersebut.

\section{HASIL DAN PEMBAHASAN}

\section{A. Hasil Penelitian}

1. Temuan Umum

a. Deskripsi Lokasi Penelitian

Penelitian ini dilakukan di kawasan

Komplek Lanata Residence 2, yang berlokasi di Jl. Aselih Jagakarsa Ciganjur, Jakarta Selatan RT 11/ RW 01 Untuk sampai ke tempat penelitian, dapat dicapai dari 2 arah yaitu dari daerah Depok dan dari arah Jagakarsa. Untuk menuju Komplek Lanata Residence 2 dapat menggunakan kendaraan pribadi maupun motor. Di kawasan ini juga berdekatan dengan Komplek Fontana Residence 1

b. Subjek Penelitian

Dalam penelitian ini yang menjadi subjek penelitian adalah 5 anak dari Komplek Lanata Residence 2. Adapun untuk nama sengaja ditulis initial QAN yang berusia 6 tahun, WH Yang berusia 5 tahun, MG yang berusia 6 tahun, JG yang berusia 5 tahun, dan LRK berusia 6 tahun.

\section{Temuan Khusus}

a. Proses Penumbuhan Aktifitas Minat Baca

Penelitian aktifitas minat yang dilakukan oleh peneliti dilakukan setiap hari Senin - Jumatuntuk waktunya relatif karena disesuaikan oleh keluarga dari subjek masing-masing. Kegiatan ini dilaksanakan di Komplek Lanata Residence 2. Diikuti oleh 5orang anak yang di dalamnya terdapat 2 (dua) anak laki-laki dan 3 (tiga) anak perempuan. Pada kegiatan membaca ini peneliti melakukan kegiatan penelitian dari bulan November 2016 hingga Februari 2017. Pada kegiatanini segala rencana kegiatan yang sudah dibuat dengan judul Penumbuhan Minat Baca Anak Usia Dini 5-6 Tahun di Komplek Lanata Residence 2.

Berdasarkan hasil penelitian dan observasi, pada saat proses belajar dan sesudah belajar anak merasa senang Ketika dibelikan buku baru yang disukai, anak langsung membacanya tanpa merasa terbebani. Dalam proses pelaksanaan aktifitas membaca ibu selalu mendampingi anaknya belajar dengan kasih sayang seperti memanggil namanya sambil mengajak membaca, ataupun bercerita, dengan membacakan maupun menemaninya belajar. Dalam bimbingan orangtua masih kurang kepada anak karena hanya dilakukan ketika ada pr atau ketika anak meminta dibacakan. Walaupun ada anak yang 
tidak bisa dipaksakan dalam belajar, dan juga anak yang belajar kalau ada pr saja kalau dibimbing dengan kasih sayang dia termotivasi untuk belajar.

\section{b. Metode Menumbuhkan Minat Baca}

Berdasarkan hasil wawancara dan observasi dengan kelima orangtua diketahui bahwa ibu dari anak yang berinisial QAN penanaman minat baca pada anak yaitu dengan cara melatih anak untuk membaca materi yang ada di buku pelajaran kemudian mengisi soal-soal pelajaran kelas 1 SD dan 2 $\mathrm{SD}$, ibu membacakan buku cerita yang berjudul Bimba, membaca tulisan yang ada pada siaran berita dan membaca komik. Inisial MG penanaman minat baca anak dengan cara melatih anak untuk membaca materi yang ada di buku kemudian mengisi soal-soal pelajaran kelas $1 \mathrm{SD}$ melalui tanya jawab oleh ibunya jika ada pertanyaan yang berkaitan dengan PR (Pekerjaan Rumah), membaca buku utsmani ( iqro ), menghafal surat-surat pendek, mencocokan pasangan gambar, membaca atau dibacakan buku-buku kisah nabi oleh ibunya. Inisial JG penanaman minat baca anak dengan cara meminta anak untuk menirukan kata-kata yang disebutkan oleh ibunya misalnya "ba" "da" , menjodohkan gambar - gambar atau tebak contoh misalnya gambar atau warna, membaca utsmani dan ibunya suka membacakan buku cerita tentang kisah-kisah nabi. Inisial LRK penanaman minat baca anak dengan cara melatih anak untuk membaca materi yang ada di buku kemudian mengisi soal-soal pelajaran yang ada di BIMBA dengan materi pelajaran kelas $1 \mathrm{SD}$, membaca buku cerita nemo, dan aku tertib berlalu lintas.

c. Media Menumbuhkan Minat Baca

Berdasarkan hasil wawancara dan observasi dengan kelima orangtua diketahui bahwa media yang digunakan anak yang berinisial QAN yaitu dengan buku-buku pelajaran kelas 1 SD dan 2 $\mathrm{SD}$, buku yang berjudul BIMBA, novel yang berjudul friends, buku yang berjudul tentang dinasaurus, binatang dan serangga, membaca komik di Handphone melalu aplikasi LINE dan tulisan berita yang ada di televisi.Anak yang berinisial MG hanya menggunakan media buku-buku bacaan saja seperti buku pelajaran tematik, buku kisah nabi, buku utsmani, buku yang berisi tentang menyempurnakan kata atau tebak gambar. Sementara anak yang berinisial JG hanya menggunakan media buku-buku bacaan saja seperti buku utsmani (iqro), bukubuku kisah nabi, buku yang berisi tentang menjodohkan gambar atau warna). Adapun anak yang berinisial LRK menggunakan media hanya kepada buku - buku bacaan saja seperti buku pelajaran, iqro, buku cerita nemo dan buku aku tertib berlalu lintas

\section{SIMPULAN DAN SARAN}

\section{A. Simpulan}

Berdasarkan pembahasan pada sub fokus penelitian, maka dapat disimpulkan sebagai berikut:

1. Proses penumbuhan minat baca anak-anak di Komplek Lanata Residence 2 masih kurang, karena anak - anak yang tinggal di Komplek Lanata Residence 2 melakukan proses penumbuhan minat baca hanya ketika ada PR dari sekolah atau ketika sedang merasa ingin membaca maupun ketika ada buku baru.

2. Metode dalam menumbuhkan minat baca dilakukan orangtua dengan berbagai cara termasuk mengajarkan anak supaya bisa membaca sehingga anak mengetahui apa yang telah dibaca diharapkan anak akan suka dan dapat menumbuhkan rasa minat baca. Berbagai metode dilakukan orangtua dalam minat baca salah satunya yaitu dengan metode seperti 1. Tiru bunyi, 2. coba tulis, 3. latih baca, 4 .tebak contoh, dan 5. latih kata dan kalimat.

3. Media dalam menumbuhkan minat baca anak-anak di Komplek Lanata Residence 2 rata-rata mengacu terhadap buku seperti buku bacaan kisah nabi, buku pelajaran, buku cerita atau novel, handphone untuk membaca komik, dan televisi untuk membaca sebuah berita yang ada tulisannya. 


\section{B. Saran}

Saran dari hasil penelitian ini:

1. Proses penumbuhan minat baca anak, orangtua harus meningkatkan bimbingan anak membaca karena membaca juga dapat menambah wawasan. Disarankan setiap hari orang tua agar setiap hari dapat membimbing anaknya dalam hal membaca

2. Terkait media dalam penumbuhan minat baca pada anak maka orangtua disarankan :

a. Bermain sambil belajar agar anak tidak merasa bosan dengan media yang sering diberikan kepada anak. Bisa juga dengan ibu membuat media bersamaan dengan anak agar anak merasa bangga dengan apa yang telah ia buat dan imajinasi anak berkembang walaupun membuat media secara sederhana.

b. Menyediakan berbagai warna, bentuk warna ukuran

c. Mengoleksi beberapa macam bukubuku bacaaan agar anak lebih tertarik, dan minat bacanya pun tumbuh di dalam dirinya.

d. Difasilitasi lebih banyak buku bacaan agar anak dapat melihatnya sehingga tumbuh minat dalam dirinya

\section{DAFTAR PUSTAKA}

Atikah S. (2011). Metode 5 langkah lancar membaca. Jakarta: Wahyumedia.

Arikunto, S. (2002). Prosedur penelitian suatu pendekatan praktek. Jakarta: Rineka Cipta

Chaplin, J.P. (2008). Kamus psikologi lengkap. Jakarta: PT Raja Grafindo.

Dimyati. (2003). Belajar dan pembelajaran. Jakarta: Rineka Cipta.

Moleong, L.J. (2005). Metodologi penelitian kualitatif. Bandung: Remaja Resdakarya.

Moleong, L.J. (2007). Metodologi penelitian kualitatif. Bandung: Remaja Resdakarya.

Mulyanto, St. L.M. (2009). Tutorial membangun multimedia interaktif media pembelajaran. Yogyakarta: Universitas Atmajaya Yogyakarta.
Nurhadi. (2004). Pembelajaran konsektual dan penerapannya dalam KBK. Malang: UM Press.

Pemerintahan Pendidikan dan Kebudayaan No 146 Tahun 2014 Pasal 1

Rahmi, F. (2008). Pengajaran membaca di Sekolah Dasar. Jakarta: Bumi Aksara

Anselm, S., Corbin, J. (2007). Dasar-dasar penelitian kualitatif. Yogyakarta : Pustaka Pelajar.

Sugiyono. (2005). Metode penelitian kuantitatif kualitatif dan $R \& D$. Bandung: Alfabeta.

Sugiyono. (2011). Metode penelitian kuantitatif kualitatif dan $R \& D$. Bandung: Alfabet.

Sujiono, Y.N. (2008). Bahan ajar perkembangan anak. Jakarta: Universitas Negri Jakarta.

Sujiono, Y.N. (2009). Konsep dasar pendidikan anak usia dini. Jakarta: Indeks.

Yusuf, S.L.N (2007). Psikologi perkembangan anak dan remaja. Bandung: PT. Remaja Rosdakarya.

Wahyuni, S. (2010). Cepat Bisa membaca Jakarta: PT Gramedias. 